\title{
Foreign Reserve Accretion and Money Supply Creation: Lebanon's Experience under an Adjustable Peg
}

\author{
Samih Antoine Azar ${ }^{1}$ \\ ${ }^{1}$ Faculty of Business Administration \& Economics, Haigazian University, Beirut, Lebanon \\ Correspondence: Samih Antoine Azar, Professor, Faculty of Business Administration \& Economics, Haigazian \\ University, Mexique Street, Kantari, Beirut, Lebanon. Tel: 961-1-349-230. E-mail: samih.azar@haigazian.edu.lb
}

Received: May 5, 2014

Accepted: May 23, 2014

Online Published: June 2, 2014

doi:10.5430/ijfr.v5n3p86

URL: http://dx.doi.org/10.5430/ijfr.v5n3p86

\begin{abstract}
The purpose of this paper is to document the relation, in post-war Lebanon from 1991 till 2013, between the central bank's foreign exchange reserves and the monetary base, and the relation between these two variables and the broad money supply in domestic currency (M2). The setting is typical of that of an open economy with a fixed exchange rate, perfect capital mobility, and widespread currency substitution, where the central bank does not conduct an independent monetary policy. In the long run a $1 \%$ rise in foreign exchange reserves leads to a $1 \%$ rise in the monetary base, a finding that supports a total lack of sterilization on the part of the Lebanese central bank. Moreover there is a long run relation between foreign exchange reserves and the broad money supply (M2), a relation that overshadows the effect of the monetary base on M2. It is as if foreign exchange reserves impact money supply directly without the intermediation of the monetary base. There is also evidence that the expansion of M2 responds significantly to consumer and business confidence. Finally the amount of domestic claims of commercial banks on the private sector does not influence M2, contrary to the prediction by post-Keynesian economists.
\end{abstract}

Keywords: foreign exchange reserves, monetary base, money supply M2, money multiplier, business confidence, perfect capital mobility, currency substitution, lack of sterilization, adjustable peg, cointegration, long run and short run relations

\section{Introduction}

"The Impossible Trinity (or trilemma of international finance) postulates that a central bank cannot conduct an independent monetary policy while simultaneously maintaining a fixed exchange rate regime and an open capital account" (Ghee and Khoon, 2011). This citation summarizes the research design and the findings of this paper on the conduct of the Lebanese central bank. Statistical evidence is presented that the Lebanese central bank made no effort to sterilize foreign exchange reserve flows, as other developing countries successfully did, and this had the effect of swelling the monetary base, and had ultimately an expansionary effect on the broad money supply in local currency (M2). This is true although the foreign exchange rate system adopted in Lebanon is not strictly speaking that of a fixed exchange rate system but rather it is that of an adjustable peg to the US dollar, which allows some thin maneuvering in the foreign exchange market, and could ease the pressures from a persistent reserve build-up. This build-up was indeed excessive. Towards the end of the year 2013 the foreign exchange reserves of the Lebanese central bank stood at 32.253 billion US dollars, up from around 600 million US dollars in early 1991, scoring a compound growth rate of $18.5 \%$ per annum over some 23 years. The monetary base and the money supply (M2) follow similar trends as Figure 1 shows. This figure has a logged left scale which has the property of converting an exponential trend to a linear trend. Figure 1 also shows that the three variables seem to have a common stochastic trend which is exactly what the econometrics will unfold later in this paper. The figure also reveals that the money supply and the foreign exchange reserves tend to move better together than they do with the monetary base, which looks more volatile relative to the other two variables. This is also a pattern that is disclosed later.

A high level of foreign exchange reserves makes it easier for policy-makers to keep a stable foreign exchange rate, because the central bank will have enough resources to finance imports, to counter a persistent current account imbalance as the one for Lebanon, and to weather shocks, especially political shocks, which predominate in Lebanon. However an automatic, accommodative and passive money creation mechanism has the unfettered consequence of generating inflation. Pegging to the US dollar, and the presence of extensive currency substitution, may have the 
advantage of anchoring the domestic inflation rate to its US counterpart, although this is not necessarily true with a policy of a passive monetization of reserve flows. The ultimate inflation will depend on the magnitude of the unsterilized foreign exchange reserve flows, and this inflation has been systematically higher than the actual US inflation, and this may lead to pressures for a devaluation of the Lebanese pound against the US dollar, although a high level of reserves may signal that the Lebanese pound is in fact undervalued and not overvalued, and needs to appreciate and not to depreciate. The fact that the US dollar has depreciated lately against the major currencies, and especially against the euro, has undoubtedly helped Lebanon to sustain the quasi fixed exchange value of its currency against the US dollar, and to orchestrate a de facto depreciation against the euro currency. This lucky state of affairs may not persist in the future. At the time of writing the US dollar has started to appreciate worldwide, and is expected by most analysts to appreciate even further.

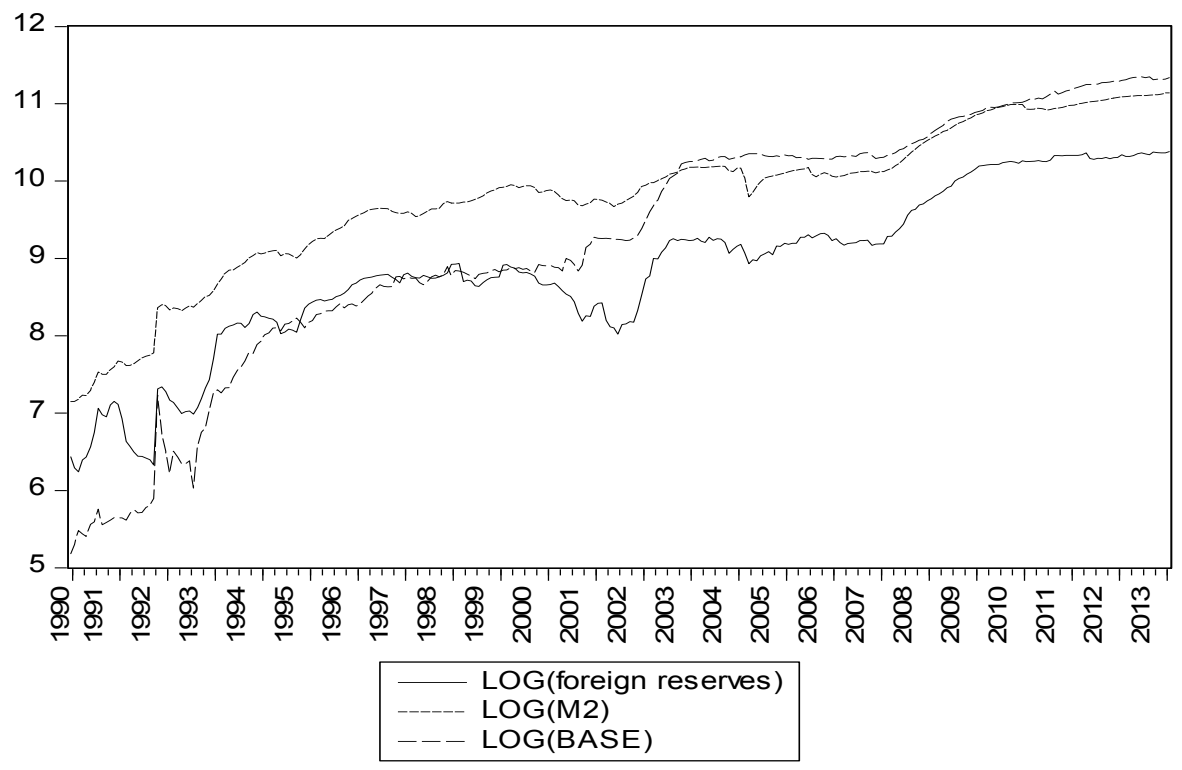

Figure 1

The paper is organized as follows. In the following section, section 2, a brief survey of the literature is provided with a stress on evidence coming mainly from developing countries. These countries were able to sterilize much of the capital inflows they have witnessed while keeping a high level of capital mobility, although it is known that high capital mobility constrains the ability to sterilize. In section 3 the theoretical and classical justification for the monetary transmission mechanism under a fixed foreign exchange rate system is presented. The empirical results make up most of section 4. Section 5 summarizes and concludes.

\section{Survey of the Literature}

A seminal paper that studied the relation between the monetary base and the money supply (M1) in the US is Baghestani and Mott (1997). They use cointegration analysis and include, besides the two variables above, a variable defined as the differential in interest rates. They estimate both long-run and short-run, error-correction, regressions. They find evidence for a long run relation in one early sub-period of the analysis. However they fail to consider the causes behind the variability in the monetary base, and stress on the determinants of the money multiplier, like the currency ratio. To date I am unaware of any other study on the US as most of the literature dwells on the economic and financial situation of developing countries. This is understandable since the US Fed has lately been modeled to follow a Taylor rule money reaction function and consequently it did not target any longer the money supply by using the monetary base.

The literature on developing countries looked essentially for two econometric coefficients. The first is the sterilization coefficient which measures the extent of neutralizing the expansionary effect of additional capital inflows, and increases in foreign reserves, by the central bank in undertaking an opposite open market operation that keeps the monetary base and the money supply unchanged. In case of an increase in capital inflows this necessitates a sale of the same magnitude of domestic securities on the open market. The sterilization coefficient is an index of the power of carrying out an independent monetary policy by a given central bank. It is inversely related to the second econometric coefficient, the offset coefficient which is an index of capital mobility. Very high capital 
mobility hampers the power of conducting an independent monetary policy. In such a case a central bank that tries to increase credit to stimulate the economy is faced with a loss in foreign reserves as the public accumulates foreign assets and amplify capital outflows, something which leads to a reversal of the expansionary policy. The more elastic the response of capital outflows is to credit expansion the higher the capital mobility and the lower the capacity of a central bank to act independently.

The statistical evidence in Fry (1995) is for an offset coefficient that is significantly less than -1, implying a rather elevated capacity of carrying out independent monetary policy despite fixed foreign exchange rates. The offset coefficient is even smaller for Pacific Basin economies. In what concerns the sterilization coefficient it is estimated in Fry (1995) to be -0.17 for 27 developing countries and -0.41 for Pacific Basin countries. This means that the latter were able to sterilize $41 \%$ of capital inflows. Fry (1995) explains this enhanced capacity of independent policy to a mixture of capital controls, capital market imperfections, non-price credit rationing of bank loans, and exchange rate flexibility.

It is clear from the above discussion that the measurement of the offset and of the sterilization coefficients depends crucially on a simultaneity problem and bias. The offset coefficient is the reaction of capital flows to domestic credit, while the sterilization coefficient is the reaction of domestic credit to capital flows. More recent empirical models have stressed this simultaneity bias, and instead of including ad hoc variables that are thought to explain solely the two dependent variables, they relied on a theoretical model developed by Brissimis et al. (2002) that they modified slightly in each case. The model is built with an explicit loss function that is minimized by the policy-makers. This loss function includes usually four indicators: the square of inflation, the square of cyclical income, the volatility of interest rates and the volatility of foreign exchange rates, and it is subject to constraints that restrict the movement of these key indicators.

Ouang et al. (2008) study 8 Asian economies. They find that capital mobility has declined over time, between the pre-crisis period and the post-crisis period. However the sterilization coefficient remained high during both periods. The authors conclude that "despite substantial capital mobility there has been a high degree of effective sterilization" of reserve flows. They caution that this policy may not remain sustainable.

Ouang et al. (2010) estimate the offset and sterilization coefficients for China during its recent history. They find that the offset coefficient is close to 0.5 , in absolute value, which denotes a moderate degree of capital mobility. This has permitted control over the build-up and monetization of foreign exchange reserves as the sterilization coefficient was relatively large and was close to 0.9 in absolute value, meaning that $90 \%$ of reserve flows were sterilized, which denotes a process of heavy sterilization. However the authors find that sterilization became increasingly difficult with the passage of time.

Ghee and Khoon (2011) study the experience of Malaysia in international finance. They find that Malaysia has monetary control in the short run but loses this control in the long run as indicated by the estimated short run and long run offset coefficients. In turn the estimated sterilization coefficients are close to $100 \%$, especially during the period with fixed rates and open account, denoting heavy sterilization efforts that were, nonetheless, ineffective because of the high offsets. They conclude that a switch to managed floating could restore monetary independence.

Downes et al. (2006) adopt a different research methodology. They consider six Caribbean countries and check for the stationarity of the money multiplier. They find that, when proper account is made about the structural shift in financial liberalization, the money multiplier becomes stationary. This implies that the central bank has control over the money supply at least in what concerns the link between the assets of the central bank and the monetary base.

\section{The Theory}

This paper tests for four key relations. The first is the relation between foreign exchange reserves of the central bank and the monetary base. The second is between the monetary base and a broad measure of the money supply (M2). The third one is between foreign exchange reserves and the broad money supply (M2). The last one is between private claims of the banking system and the broad money supply (M2). The first relation is a form of open market operation. It is found that the Lebanese central bank does not sterilize reserve flows because there is both a short run and a long run relation between these reserve flows and the monetary base. Moreover the long run impact is insignificantly different from +1 . Therefore this unsterilized open market operation has the following effect: an exogenous increase (or decrease), in foreign exchange reserves, leads to an increase (decrease) in the monetary base. This scheme is classic and is described in all textbooks of monetary economics. See for example Mishkin (2013). Lavoie and Wang (2012) challenge this transmission mechanism and argue that the increase in reserves will be used to downsize banks' borrowings from the central bank leading to no change in the monetary base. While this looks like a sterilization of reserve changes it is in fact an endogenous "compensation" as Lavoie and Wang (2012) call it. 
The relation between the monetary base and M2 should be through the money multiplier. A stationary multiplier implies that an increase (decrease) in the monetary base leads to an increase (decrease) in the money supply. Therefore there should be both a short and a long run relation between the two variables. Since foreign reserves changes lead to changes in the monetary base then there should be a short run and a long run relation between reserve changes and changes in M2. Finally some authors, mostly post-Keynesian economists, hold the view that money supply is created by banks from the expansion of their loans to the private sector, and not through a central bank multiplier process. This claim is also tested for Lebanon but is found to be non-existent.

The monetary transmission mechanism described so far assumes implicitly that the foreign exchange rate is fixed. Although not totally fixed the exchange rate mechanism in Lebanon is a variant of a fixed rate system as it is an adjustable peg to the US dollar. Since by an adjustable peg the central bank relinquishes control on the foreign exchange rate then the monetary transmission mechanism is endogenous: an accretion of foreign reserves leads to a higher monetary base which, in turn, leads to a higher money supply. Hence and independent monetary policy cannot be pursued. This is true in the Mundel-Fleming IS/LM paradigm under perfect capital mobility. Any attempt to increase the money supply independently under fixed exchange rates, and perfect capital mobility, will lead to reserve outflows and currency substitution. Monetary policy is totally ineffective in this situation. Perfect capital mobility is a salient feature of the Lebanese economy. And the additional fact that the Lebanese central bank did not attempt to sterilize foreign reserve flows makes the conduct of an independent monetary policy quasi impossible. Therefore Lebanon seems to distance itself from other developing nations who were able to follow an independent monetary policy under fixed rates by the use of a combination of exchange controls to limit capital mobility, partial sterilization of reserve flows, and some limited flexibility in foreign exchange rate management. The reason why Lebanon did not do the same is unclear. But the statistical evidence is strong that it did not do the same.

\section{The Empirical Results}

The data is retrieved from the web page of the central bank of Lebanon, the Banque du Liban. There are six variables of interest: foreign exchange reserves of the central bank in Lebanese pounds (forll) and in US dollars (fordol), the monetary base (base), the money supply (M2), the claims of the banking system upon the private sector in Lebanese pounds (claimsll), and the coincident indicator (CI) compiled by the central bank to measure consumer and business confidence. This indicator will be assumed to have an impact on money supply creation by the banking system for the simple reason that banks will use up their excess reserves at the central bank and create money whenever the business outlook is better. So, it is not enough that the central bank increases the banks' reserves on its balance sheet but banks need to respond by holding as little excess reserves as possible. For example lately the US banks have failed to extend credit and create money despite huge increases in the monetary base, carried out by the Fed's quantitative easing, simply because there was a lack of confidence in the credit system. Therefore the actions of a central bank cannot materialize without the help of the banking system. The central bank can pull the line but cannot push it. Hence if banks do not run down their excess reserves and extend credit the money supply creation process is hampered.

In Table 1 the logged variables are tested for stationarity. The test adopted is the Elliott et al.'s unit root test (1996).The null hypotheses that there is a unit root in the log-levels fail to be rejected, while the same nulls for the differenced series are rejected at marginal significance levels well below $1 \%$. The only discrepancy is the log of the coincident indicator for which the null of a unit root fails to be rejected if the test is without a trend, but is rejected if the test includes a trend. It is decided to consider all variables non-stationary in log levels but stationary in the changes of the logs.

Table 1. Elliott-Rothenberg-Stock point-optimal unit root tests with a constant and a trend

\begin{tabular}{lcc}
\hline \multicolumn{1}{c}{$Z$} & Test on $\log Z$ & Test on $\Delta(\log Z)$ \\
\hline Coincident indicator $(\mathrm{CI})$ & $165.2904(>10 \%)$ & $0.031776(<1 \%)$ \\
Monetary base (base) & $28.59158(>10 \%)$ & $2.912086(<1 \%)$ \\
Claims of commercial banks in Lebanese pounds on private sector (claimsll) & $84.49826(>10 \%)$ & $0.773226(<1 \%)$ \\
Foreign exchange reserves of central bank in US dollars (fordol) & $11.28047(>10 \%)$ & $1.118693(<1 \%)$ \\
Foreign exchange reserves of central bank in Lebanese pounds (forll) & $8.831419(>10 \%)$ & $1.263854(<1 \%)$ \\
Money supply (M2) & $29.18231(>10 \%)$ & $0.798679(<1 \%)$ \\
\hline
\end{tabular}

Notes: $\log$ stands for the natural logarithm. $\Delta$ stands for the first-difference operator. All variables are monthly from January 1993 to November 2013, i.e. 251 observations for each Z. The null hypothesis is a unit root. In parenthesis are magnitudes of the actual p-values. The unit root test on the coincident indicator excludes a trend, but includes a constant. 
In Table 2 regressions of the logged foreign exchange reserves on the logged monetary base are conducted. The specifications, which will be similar for all subsequent regressions in subsequent tables, are based on the error-correction model. Two variants of this model are implemented. The first is by including the two lagged log-level variables in the short run regression between the change in logged reserves and the change in the logged monetary base. And the second variant is to include the lagged cointegration residual in the short run relation. The latter residual is obtained by an Ordinary Least Squares (OLS) regression of the logged reserves on the logged monetary base. See details in the notes to Table 2 . The regressions take separately foreign exchange reserves in Lebanese pounds and in US dollars. The results and the estimated coefficients do not materially change with the denomination of the foreign exchange reserves. For example the short run impact of the change in the logged foreign exchange reserves in Lebanese pounds on the change in the logged monetary base is 0.3981 while the impact of the change in the logged foreign exchange reserves in US dollars on the change in the logged monetary base is 0.3715 . The two adjustment coefficients are also quite close, being -0.0213 and -0.0205 respectively. Moreover the long run cointegration vectors are again very close to each other, being 0.8808 and 1.0091 respectively, and both these estimates are insignificantly different from +1 . This means that in the long run a $1 \%$ increase in foreign exchange reserves, whether measured in Lebanese pounds or in US dollars, leads to a $1 \%$ increase in the monetary base. The short run impacts are smaller at around 0.3981 and 0.3715 respectively.

These results obtain for the bigger sample size, from January 1991 to January 2014. The results for the smaller sample (March 1993 to November 2013) are similar. The short run effects are somewhat smaller than before at 0.1643 and 0.1702 respectively, but again these two estimates are very close to each other. The long run effects are 0.9473 and 0.9654 respectively and are also close to each other and immaterially different from +1 . The adjustment coefficients are -0.0203 and -0.0201 respectively.

When the lagged cointegration residual is included (columns 6 and 7 of Table 1) the adjustment coefficients are somewhat smaller at -0.0119 and -0.01229 respectively, and the short run effects are both equal to 0.2608 . All coefficients in the six regressions in Table 1 are statistically significantly different from zero except for the cointegration constant in the first four regressions (columns 2 to 4 of Table 1). In what concerns the conditional variance equations a GARCH(1,1) model is selected for the first four regressions and an EGARCH model (Nelson, 1991) for the last two regressions. The standardized residuals are all well-behaved. In general, high-order serial correlation and high-order ARCH effects are absent from these standardized residuals.

In Table 3 regressions on the change in logs of the money supply M2 are conducted with a specification similar to those in Table 2. In column 2 of Table 3 the short run relation includes the change in the log of the monetary base, the change in the logs of the coincident indicator and the lagged change in the logs of the M2 money supply. The coefficients on these three variables are statistically significantly different from zero and are positive. Therefore there is a short run relation between the growth rates of the monetary base and the coincident indicator with the growth rate in M2. Hence consumer and business confidence impacts significantly money creation as expected intuitively. Again, in the same regression, the three lagged log-levels variables are included. The adjustment coefficient is -0.02383 and is statistically significant. While the coincident indicator has a significant long run cointegration relation with M2 the same cannot be said about the monetary base, whose long run cointegration coefficient has a t-statistic of 0.2225 . The lack of a long run relation between the monetary base and M2 is puzzling.

Table 2. Regressions with $\Delta\left(\log \left(\right.\right.$ base $\left.\left._{\mathrm{t}}\right)\right)$ as the dependent variable

\begin{tabular}{|c|c|c|c|c|c|c|}
\hline \multirow{3}{*}{ Sample } & 1991M01-2014 & 1991M01-2014 & 1993M03-2013 & 1993M03-2013 & 1993M03-2013 & 1993M03-2013 \\
\hline & M01 & M01 & M11 & M11 & M11 & M11 \\
\hline & $\mathrm{N}=277$ & $\mathrm{~N}=277$ & $\mathrm{~N}=250$ & $\mathrm{~N}=250$ & $\mathrm{~N}=250$ & $\mathrm{~N}=250$ \\
\hline \multicolumn{7}{|c|}{ Conditional mean equation: } \\
\hline \multirow[t]{2}{*}{ constant } & & & & & 0.008787 & 0.008717 \\
\hline & & & & & $(6.197068)$ & $(6.150672)$ \\
\hline \multirow[t]{2}{*}{$\Delta\left(\log \left(\right.\right.$ forll $\left.\left._{\mathrm{t}}\right)\right)$} & 0.398137 & & 0.164281 & & 0.260770 & \\
\hline & $(30.90177)$ & & $(4.419949)$ & & $(20.53560)$ & \\
\hline \multirow[t]{2}{*}{$\Delta\left(\log \left(\right.\right.$ fordol $\left.\left._{\mathrm{t}}\right)\right)$} & & 0.371486 & & 0.170181 & & 0.260821 \\
\hline & & $(36.67533)$ & & $(4.362379)$ & & $(20.55353)$ \\
\hline \multirow[t]{2}{*}{$\Delta\left(\log \left(\right.\right.$ base $\left.\left._{\mathrm{t}-1}\right)\right)$} & & & 0.118505 & 0.132310 & & \\
\hline & & & $(2.187851)$ & $(2.441526)$ & & \\
\hline $\log \left(\right.$ base $\left._{t-1}\right)$ & -0.021262 & -0.020530 & -0.020298 & -0.020088 & & \\
\hline
\end{tabular}




\begin{tabular}{|c|c|c|c|c|c|c|}
\hline & $(3.153228)$ & $(2.993893)$ & $(2.880046)$ & $(2.748386)$ & & \\
\hline \multicolumn{7}{|l|}{$\begin{array}{c}\text { Cointegration regression } \\
\text { coefficients: }\end{array}$} \\
\hline constant & $\begin{array}{c}2.046296 \\
(1.326453)\end{array}$ & $\begin{array}{c}1.151715 \\
(0.922688)\end{array}$ & $\begin{array}{c}1.413084 \\
(0.900171)\end{array}$ & $\begin{array}{c}1.615057 \\
(1.098107)\end{array}$ & & \\
\hline $\log \left(\right.$ forll $\left._{t-1}\right)$ & $\begin{array}{c}0.880857 \\
(6.376437)\end{array}$ & & $\begin{array}{c}0.947253 \\
(6.829833)\end{array}$ & & & \\
\hline $\log \left(\right.$ fordol $\left._{t-1}\right)$ & & $\begin{array}{c}1.009096 \\
(8.821582)\end{array}$ & & $\begin{array}{c}0.965357 \\
(7.176952)\end{array}$ & & \\
\hline $\begin{array}{c}\text { Lagged cointegration } \\
\text { residual } \\
\end{array}$ & & & & & $\begin{array}{l}-0.011933 \\
(4.787630) \\
\end{array}$ & $\begin{array}{l}-0.012291 \\
(4.767968) \\
\end{array}$ \\
\hline \multicolumn{7}{|l|}{$\begin{array}{l}\text { IGARCH conditional } \\
\text { variance equation: }\end{array}$} \\
\hline $\operatorname{RESID}_{\mathrm{t}-1} \wedge 2$ & $\begin{array}{c}0.087641 \\
(7.233344)\end{array}$ & $\begin{array}{c}0.084549 \\
(7.285409)\end{array}$ & $\begin{array}{c}0.074909 \\
(7.725095)\end{array}$ & $\begin{array}{c}0.074337 \\
(7.616623)\end{array}$ & & \\
\hline $\mathrm{GARCH}_{\mathrm{t}-1}$ & $\begin{array}{c}0.912359 \\
(75.30023)\end{array}$ & $\begin{array}{c}0.915451 \\
(78.88294)\end{array}$ & $\begin{array}{c}0.925091 \\
(95.40191)\end{array}$ & $\begin{array}{c}0.925663 \\
(94.84355)\end{array}$ & & \\
\hline \multicolumn{7}{|l|}{$\begin{array}{l}\text { EGARCH conditional } \\
\text { variance equation: } \\
\text { LOG(GARCH) }\end{array}$} \\
\hline Constant & & & & & $\begin{array}{l}-1.717274 \\
(4.534395)\end{array}$ & $\begin{array}{l}-1.661217 \\
(4.541587)\end{array}$ \\
\hline $\begin{array}{c}\text { ABS }\left(\text { RESID }_{\mathrm{t}-1}\right) / \mathrm{SQRT}(\mathrm{GAR} \\
\left.\mathrm{CH}_{\mathrm{t}-1}\right)\end{array}$ & & & & & $\begin{array}{c}1.002197 \\
(8.337778)\end{array}$ & $\begin{array}{c}0.990623 \\
(8.297453)\end{array}$ \\
\hline $\operatorname{RESID}_{\mathrm{t}-1} / \mathrm{SQRT}\left(\mathrm{GARCH}_{\mathrm{t}-1}\right)$ & & & & & $\begin{array}{l}-0.226250 \\
(3.064730)\end{array}$ & $\begin{array}{l}-0.219860 \\
(2.986115)\end{array}$ \\
\hline $\mathrm{LOG}\left(\mathrm{GARCH}_{\mathrm{t}-1}\right)$ & & & & & $\begin{array}{c}0.850028 \\
(16.62547) \\
\end{array}$ & $\begin{array}{c}0.857393 \\
(17.39222) \\
\end{array}$ \\
\hline Adjusted R-square & 0.315962 & 0.349750 & 0.110326 & 0.119921 & 0.086334 & 0.087800 \\
\hline \multicolumn{7}{|l|}{ Ljung-Box Q-statistic: } \\
\hline $\mathrm{K}=6$ & 0.556 & 0.559 & 0.493 & 0.005 & 0.831 & 0.832 \\
\hline $\mathrm{K}=12$ & 0.439 & 0.473 & 0.229 & 0.023 & 0.548 & 0.558 \\
\hline $\mathrm{K}=24$ & 0.371 & 0.341 & 0.598 & 0.188 & 0.755 & 0.767 \\
\hline \multicolumn{7}{|l|}{ Ljung-Box $Q^{2}$-statistic: } \\
\hline $\mathrm{K}=6$ & 0.738 & 0.571 & 0.987 & 0.110 & 0.835 & 0.848 \\
\hline $\mathrm{K}=12$ & 0.940 & 0.897 & 0.978 & 0.212 & 0.968 & 0.972 \\
\hline $\mathrm{K}-24$ & 0.923 & 0.344 & 0.037 & 0.000 & 0.015 & 0.013 \\
\hline
\end{tabular}

Notes: See Table 1 and the notes under it. In parenthesis are absolute t-statistics. The cointegration regression residuals are respectively $\log$ (base) $+2.846018-1.324198^{*} \log$ (forll), and $\log$ (base) +1.974674 $1.290652 * \log$ (fordol). The Q-statistics are on the standardized residuals. The $\mathrm{Q}^{2}$-statistics are on the squares of the standardized residuals. The lag length of both these statistics is K. Actual p-values are reported for the Q-statistics and the $\mathrm{Q}^{2}$-statistics.

In columns 3 and 4 of Table 3, the two variables for the foreign exchange reserves are added to the regression each variable separately with the monetary base and the coincident indicator. 
Table 3. Regressions with $\Delta\left(\log \left(\mathrm{M} 2_{\mathrm{t}}\right)\right)$ as the dependent variable

\begin{tabular}{|c|c|c|c|}
\hline Conditional mean equation: & & & \\
\hline \multirow[t]{2}{*}{$\Delta\left(\log \left(\right.\right.$ base $\left.\left._{t}\right)\right)$} & 0.093624 & 0.044261 & 0.043048 \\
\hline & $(2.744395)$ & $(1.278059)$ & $(1.253611)$ \\
\hline \multirow[t]{2}{*}{$\Delta\left(\log \left(\right.\right.$ forl $\left.\left.1_{t}\right)\right)$} & & 0.160565 & \\
\hline & & $(6.831538)$ & \\
\hline \multirow[t]{2}{*}{$\Delta\left(\log \left(\right.\right.$ fordol $\left.\left._{\mathrm{t}}\right)\right)$} & & & 0.161736 \\
\hline & & & $(6.994997)$ \\
\hline \multirow[t]{2}{*}{$\Delta\left(\log \left(C_{t}\right)\right)$} & 0.129109 & 0.111660 & 0.112619 \\
\hline & $(7.198405)$ & $(5.367075)$ & $(5.435214)$ \\
\hline \multirow[t]{2}{*}{$\Delta\left(\log \left(\mathrm{M} 2_{\mathrm{t}-1}\right)\right)$} & 0.538015 & 0.374354 & 0.369526 \\
\hline & $(9.729698)$ & $(6.744833)$ & $(6.765167)$ \\
\hline \multirow[t]{2}{*}{$\log \left(\mathrm{M} 2_{\mathrm{t}-1}\right)$} & -0.023828 & -0.026099 & -0.026906 \\
\hline & $(3.327274)$ & $(2.690548)$ & $(2.686163)$ \\
\hline \multicolumn{4}{|l|}{ Cointegration regression coefficients: } \\
\hline \multirow[t]{2}{*}{ constant } & -0.314160 & -0.500681 & -0.227195 \\
\hline & $(0.169770)$ & $(0.210319)$ & $(0.097512)$ \\
\hline \multirow[t]{2}{*}{$\log \left(\right.$ base $\left._{t-1}\right)$} & -0.03102 & -0.123400 & -0.129239 \\
\hline & $(0.222532)$ & $(0.497337)$ & $(0.534102)$ \\
\hline \multirow[t]{2}{*}{$\log \left(\right.$ forll $\left._{\mathrm{t}-1}\right)$} & & 0.381352 & \\
\hline & & $(1.963316)$ & \\
\hline \multirow[t]{2}{*}{$\log \left(\right.$ fordol $\left._{t-1}\right)$} & & & 0.396887 \\
\hline & & & $(2.142481)$ \\
\hline \multirow[t]{2}{*}{$\log \left(\mathrm{CI}_{\mathrm{t}-1}\right)$} & 2.129352 & 1.611322 & 1.572358 \\
\hline & $(3.196598)$ & $(1.620829)$ & $(1.646739)$ \\
\hline \multicolumn{4}{|l|}{ EGARCH conditional variance equation: } \\
\hline \multicolumn{4}{|l|}{$\mathrm{LOG}(\mathrm{GARCH})$} \\
\hline \multirow[t]{2}{*}{ Constant } & -2.061884 & -2.833948 & -2.860493 \\
\hline & $(4.097005)$ & $(3.277571)$ & $(3.234205)$ \\
\hline \multirow[t]{2}{*}{$\operatorname{ABS}\left(\mathrm{RESID}_{\mathrm{t}-1}\right) / \mathrm{SQRT}\left(\mathrm{GARCH}_{\mathrm{t}-1}\right)$} & 0.415713 & 0.478849 & 0.470486 \\
\hline & $(4.633839)$ & $(4.439055)$ & $(4.447028)$ \\
\hline \multirow[t]{2}{*}{$\mathrm{RESID}_{\mathrm{t}-1} / \mathrm{SQRT}\left(\mathrm{GARCH}_{\mathrm{t}-1}\right)$} & -0.290546 & -0.253093 & -0.256493 \\
\hline & $(4.743443)$ & $(3.396748)$ & $(3.459970)$ \\
\hline \multirow[t]{2}{*}{$\mathrm{LOG}\left(\mathrm{GARCH}_{\mathrm{t}-1}\right)$} & 0.776031 & 0.686433 & 0.682417 \\
\hline & $(12.91588)$ & $(6.509370)$ & $(6.309982)$ \\
\hline Adjusted R-square & 0.214561 & 0.375268 & 0.379406 \\
\hline \multicolumn{4}{|l|}{ Ljung-Box Q-statistic: } \\
\hline $\mathrm{K}=6$ & 0.055 & 0.336 & 0.209 \\
\hline $\mathrm{K}=12$ & 0.288 & 0.499 & 0.417 \\
\hline $\mathrm{K}=24$ & 0.145 & 0.551 & 0.519 \\
\hline \multicolumn{4}{|l|}{ Ljung-Box $Q^{2}$-statistic: } \\
\hline $\mathrm{K}=6$ & 0.449 & 0.964 & 0.937 \\
\hline $\mathrm{K}=12$ & 0.544 & 0.957 & 0.941 \\
\hline $\mathrm{K}-24$ & 0.019 & 0.266 & 0.280 \\
\hline
\end{tabular}

Notes: See Tables 1 and 2.

In these two regressions the short run effect of the monetary base dissipates and the long run effect is still insignificant. However the short run and long run cointegration effects of the two denominations of the foreign exchange reserves are statistically significant. However the long run cointegration effect of the coincident indicator becomes insignificant. This is probably due to the presence of the monetary base variable. This is true because Table 4 repeats the two regressions of columns 3 and 4 of Table 3 without the monetary base variable, but including the foreign exchange reserves and the coincident indicator. All short run and long run cointegration coefficients are now statistically significant. Moreover the results of the two regressions on each denomination of foreign exchange 
reserves are very close to each other. The short run coefficients on the foreign exchange reserves are 0.1747 and 0.1748 respectively. The short run coefficients on the coincident indicator are 0.1021 and 0.0977 respectively. And the coefficients on the lagged growth rate in M2 are 0.3639 and 0.3434 respectively. The coefficients that stand for the adjustment to the long run are -0.0330 and -0.0347 respectively. The long run cointegration coefficients on each denomination of foreign exchange reserves are 0.3605 and 0.3885 respectively. And the long run cointegration coefficients on the coincident indicator are 1.2327 and 1.1411 respectively, and are insignificantly different from +1 .

Table 4. Regressions with $\Delta\left(\log \left(\mathrm{M}_{\mathrm{t}}\right)\right)$ as the dependent variable

\begin{tabular}{|c|c|c|c|c|}
\hline \multicolumn{5}{|l|}{ Conditional mean equation: } \\
\hline \multirow[t]{2}{*}{ constant } & & & 0.004846 & 0.004911 \\
\hline & & & $(3.055419)$ & $(3.109784)$ \\
\hline \multirow[t]{2}{*}{$\Delta\left(\log \left(\right.\right.$ forll $\left.\left._{t}\right)\right)$} & 0.174743 & & 0.177432 & \\
\hline & $(8.917723)$ & & $(9.493077)$ & \\
\hline \multirow[t]{2}{*}{$\Delta\left(\log \left(\right.\right.$ fordol $\left.\left._{t}\right)\right)$} & & 0.174809 & & 0.179182 \\
\hline & & $(8.761782)$ & & $(9.712776)$ \\
\hline \multirow[t]{2}{*}{$\Delta\left(\log \left(\mathrm{CI}_{\mathrm{t}}\right)\right)$} & 0.102056 & 0.097694 & 0.102545 & 0.101849 \\
\hline & $(5.723076)$ & $(5.536620)$ & $(6.331573)$ & $(6.317208)$ \\
\hline \multirow[t]{2}{*}{$\Delta\left(\log \left(\mathrm{M} 2_{\mathrm{t}-1}\right)\right)$} & 0.363917 & 0.343363 & 0.362734 & 0.355198 \\
\hline & $(6.986774)$ & $(6.271977)$ & $(7.165645)$ & (7.094727) \\
\hline \multirow[t]{2}{*}{$\log \left(\mathrm{M} 2_{\mathrm{t}-1}\right)$} & -0.033020 & -0.034666 & & \\
\hline & $(4.442223)$ & $(4.488268)$ & & \\
\hline \multirow[t]{2}{*}{ lagged cointegration residual } & & & -0.030550 & -0.032915 \\
\hline & & & $(4.611000)$ & $(4.758966)$ \\
\hline \multicolumn{5}{|l|}{ Cointegration regression coefficients: } \\
\hline \multirow[t]{2}{*}{ constant } & 0.441412 & 0.820152 & & \\
\hline & $(0.514117)$ & $(0.918616)$ & & \\
\hline \multirow[t]{2}{*}{$\log \left(\right.$ forll $\left._{t-1}\right)$} & 0.360450 & & & \\
\hline & $(2.432357)$ & & & \\
\hline \multirow[t]{2}{*}{$\log \left(\right.$ fordol $\left._{t-1}\right)$} & & 0.388540 & & \\
\hline & & $(2.769378)$ & & \\
\hline \multirow[t]{2}{*}{$\log \left(\mathrm{CI}_{\mathrm{t}-1}\right)$} & 1.232673 & 1.141105 & & \\
\hline & $(3.052965)$ & $(2.908807)$ & & \\
\hline \multicolumn{5}{|l|}{ EGARCH conditional variance equation: } \\
\hline \multicolumn{5}{|l|}{ LOG(GARCH) } \\
\hline \multirow[t]{2}{*}{ Constant } & -2.722514 & -2.658492 & -2.667722 & -2.656657 \\
\hline & $(3.478529)$ & $(3.436240)$ & $(3.280175)$ & $(3.241241)$ \\
\hline \multirow[t]{2}{*}{ ABS(RESID $\left.{ }_{t-1}\right) / S Q R T\left(G_{A R C H}{ }_{t-1}\right)$} & 0.505143 & 0.509213 & 0.508916 & 0.512513 \\
\hline & $(4.676797)$ & $(4.783909)$ & $(4.994919)$ & $(5.000127)$ \\
\hline \multirow[t]{2}{*}{$\mathrm{RESID}_{\mathrm{t}-1} / \mathrm{SQRT}\left(\mathrm{GARCH}_{\mathrm{t}-1}\right)$} & -0.245003 & -0.239735 & -0.226087 & -0.228496 \\
\hline & $(3.357633)$ & $(3.295276)$ & $(3.334636)$ & $(3.318490)$ \\
\hline \multirow[t]{2}{*}{$\mathrm{LOG}\left(\mathrm{GARCH}_{\mathrm{t}-1}\right)$} & 0.703873 & 0.713024 & 0.710270 & 0.712233 \\
\hline & $(7.503053)$ & $(7.683169)$ & $(7.233658)$ & $(7.203701)$ \\
\hline Adjusted R-square & 0.387069 & 0.392207 & 0.389768 & 0.394292 \\
\hline \multicolumn{5}{|l|}{ Ljung-Box Q-statistic: } \\
\hline $\mathrm{K}=6$ & 0.167 & 0.145 & 0.175 & 0.177 \\
\hline $\mathrm{K}=12$ & 0.378 & 0.359 & 0.400 & 0.398 \\
\hline$K=24$ & 0.520 & 0.498 & 0.583 & 0.565 \\
\hline \multicolumn{5}{|l|}{ Ljung-Box $Q^{2}$-statistic: } \\
\hline $\mathrm{K}=6$ & 0.923 & 0.908 & 0.958 & 0.961 \\
\hline $\mathrm{K}=12$ & 0.947 & 0.939 & 0.955 & 0.957 \\
\hline $\mathrm{K}-24$ & 0.323 & 0.269 & 0.236 & 0.245 \\
\hline
\end{tabular}

Notes: See Tables 1 and 2. The cointegration regression, with the variable forll (column 4), is $\log (\mathrm{M} 2)=0.046549+0.495759 * \log ($ forll $)+1.026809 * \log (\mathrm{CI})$, and, with the variable fordol (column 5), it is $\log (\mathrm{M} 2)=0.649265+0.531145 * \log ($ fordol $)+0.887421 * \log (\mathrm{CI})$. 
In Table 4 columns 4 and 5, the same regressions as their counterparts in columns 2 and 3 are estimated with the difference that the lagged log-level variables are replaced by the lagged cointegration residual. The cointegration regression is estimated by OLS and its two specifications are reported in the notes under Table 4 . The results are very close to each other. The short run coefficients on the two denominations of the foreign exchange reserves are 0.1774 and 0.1792 respectively while in columns 2 and 3 they were 0.1747 and 0.1748 respectively. The short run coefficients on the coincident indicator are 0.1026 and 0.1018 respectively while previously they were 0.1021 and 0.0977 respectively. The coefficients on the lagged growth rates of the money supply M2 are 0.3627 and 0.3552 while they were previously 0.3639 and 0.3434 . Finally the adjustment coefficients on the lagged cointegration residual are -0.0306 and -0.0329 respectively, and are highly statistically significant.

All the coefficients in the EGARCH specifications of the conditional variance in the four regressions of Table 4 are statistically significant, and have estimates close to each other, whatever the specification and the included variables in the regressions. These EGARCH models provide evidence for a leverage effect, meaning that negative shocks to the conditional mean equation raise the conditional variance. The reason for a leverage effect is not known. Finally the adjusted R-squares are high for monthly data, at around 39\%. The standardized residuals are well-behaved with an absence of high-order serial correlation and high-order ARCH effects.

The results in Table 3 and 4 point to the existence of a significant relation between foreign exchange reserves and the coincident indicator both with the money supply, a relation that overshadows the independent effect of the monetary base on M2. It is as if foreign exchange reserves impact directly the money supply without the intermediation of the monetary base. The reason for this direct and positive relation is unknown.

Table 5. Regressions with $\Delta\left(\log \left(\mathrm{M} 2_{\mathrm{t}}\right)\right)$ as the dependent variable

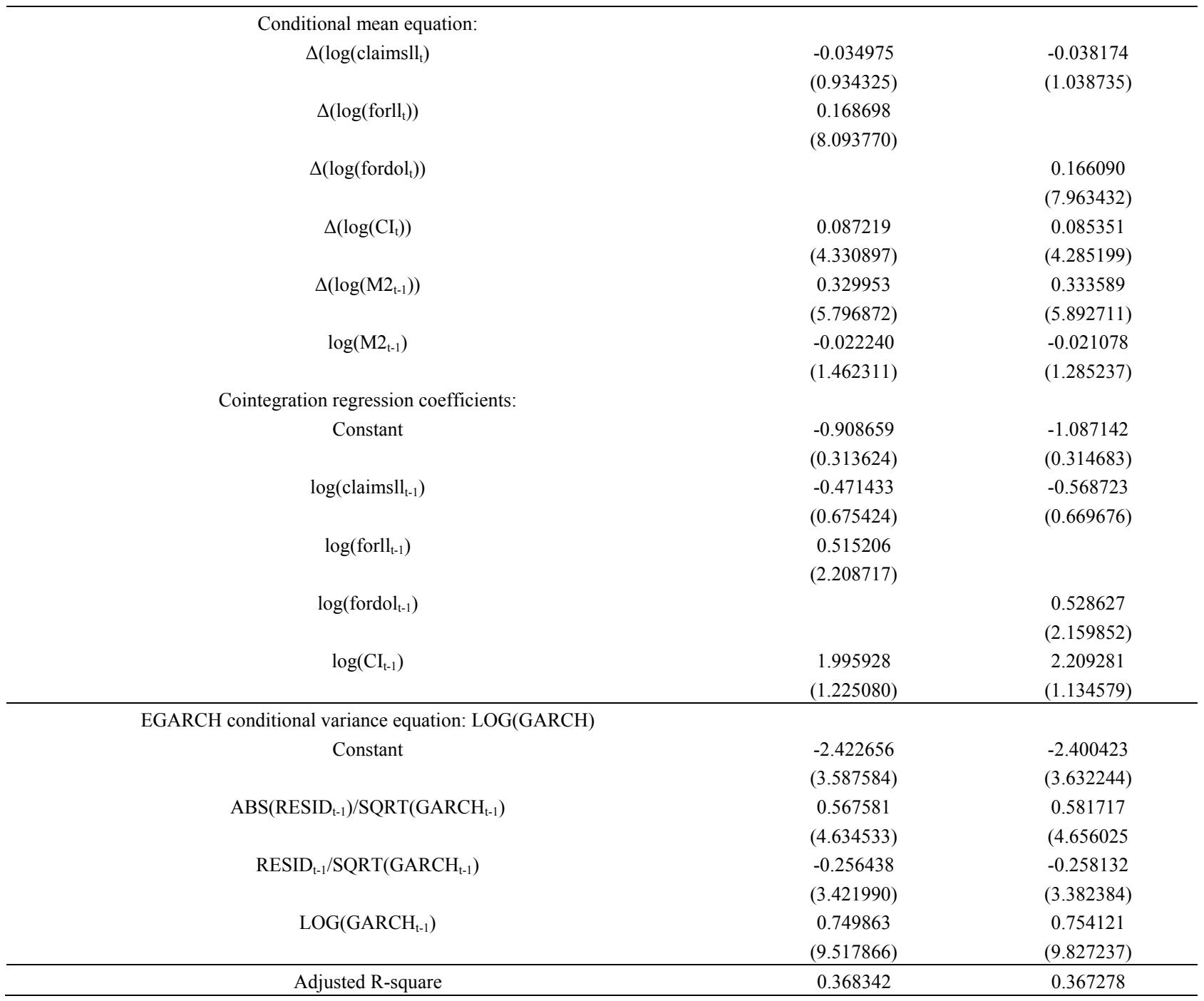

Notes: See Tables 1 and 2. 
In Table 5 regressions similar to the regressions in columns 2 and 3 of Table 4 are estimated. The only difference is that another variable is included which is the claims in Lebanese pounds of the banking system on the private sector. These claims are nothing else than total loans in Lebanese pounds of the banking system to the private sector. According to post-Keynesian economists loans drive the money supply. If this is true then there should be statistically significant short run and long run coefficients between this variable and the money supply M2. The results do not support such a hypothesis. The Wald tests that the two short run and long run coefficients in the two specifications are jointly equal to zero have actual p-values of 0.5650 and 0.5232 respectively, which implies that the underlying variable does not add explanatory power once foreign exchange reserves and the coincident indicator are included.

\section{Conclusion}

This paper studies money creation in Lebanon during the post-war period. The main purpose is to document the relation between the central bank's foreign exchange reserves and the monetary base, and the relation between these two variables and the broad money supply in domestic currency (M2). The model is that of an open economy with a fixed exchange rate, perfect capital mobility, and widespread currency substitution. As a result the central bank does not conduct an independent monetary policy. In the long run a $1 \%$ rise in foreign exchange reserves leads to a $1 \%$ rise in the monetary base, a finding that supports a total lack of sterilization on the part of the Lebanese central bank. Moreover there is a long run cointegration relation between foreign exchange reserves and the broad money supply (M2), a relation that overshadows the effect of the monetary base on M2. It is as if foreign exchange reserves, whether denominated in Lebanese pounds or in US dollars, impact money supply directly without the intermediation of the monetary base. There is also evidence that the expansion of M2 responds positively and significantly to consumer and business confidence. Finally the amount of domestic claims of commercial banks on the private sector does not influence M2, contrary to the prediction of post-Keynesian economists.

\section{References}

Baghestani, H., \& Mott, T. (1997). A cointegration analysis of the U.S. money supply process. Journal of Macroeconomics, 19(2), 269-283. http://dx.doi.org/10.1016/S0164-0704(97)00015-3

Brissimis, S., Gibson, H., \& Tsakalotos, E. (2002). A unifying framework for analyzing offsetting capital flows and sterilization: Germany and the ERM. International Journal of Finance and Economics, 7, 63-78. http://dx.doi.org/10.1002/ijfe.171

Downes, D., Moore, W., \& Jackson, D. (2006). Financial liberalization and the stationarity of money multiplier. International Economic Journal, 20(2), 227-240. http://dx.doi.org/10.1080/10168730600699507

Elliot, G., Rothenberg, T. J., \& Stock, J. H. (1996). Efficient tests for an autoregressive unit root. Econometrica, 64, 813-836. http://dx.doi.org/10.2307/2171846

Fry, M. J. (1995). Money, interest, and banking in economic development. Baltimore: Johns Hopkins University Press.

Ghee, L. E., \& Khoon, G. S. (2011). Is Malaysia exempted from the impossibility trinity? An empirical analysis from 1991-2009. CenPRIS working paper 140/11.

Lavoie, M., \& Wang, P. (2012). The 'compensation' thesis, as exemplified by the case of the Chinese central bank. International Review of Applied Economics, 26(3), 287-301. http://dx.doi.org/10.1080/02692171.2011.587108

Mishkin, F. S. (2013). The economics of money, banking, and financial markets (10 ${ }^{\text {th }}$ Global ed.). Boston: Pearson.

Nelson, D. B. (1991). Conditional heteroskedasticity in asset returns: A new approach. Econometrica, 59, 347-370. http://dx.doi.org/10.2307/2938260

Ouyang, A. Y., Rajan, R. S., \& Willett, T. D. (2008). Managing the monetary consequences of reserve accumulation in emerging Asia. Global Economic Review, 37, 171-199. http://dx.doi.org/10.1080/12265080802021185

Ouyang, A. Y., Rajan, R. S., \& Willett, T. D. (2010). China as a reserve sink: The evidence form offset and sterilization coefficients. Journal of International Money and Finance, 29, 951-972. http://dx.doi.org/10.1016/j.jimonfin.2009.12.006 